\title{
POTENSI MINYAK ATSIRI KULIT BUAH JERUK NIPIS UNTUK PENGENDALIAN CROCIDOLOMIA PAVONANA
}

\author{
Nidia Melati Al Anshori ${ }^{1)}$, Retno Wijayanti ${ }^{2)}$, Ato Sulistyo ${ }^{2)}$ \\ 1) Mahasiswa Program Studi Agroteknologi, Fakultas Pertanian Universitas Sebelas Maret Surakarta \\ 2) Dosen Program Studi Agroteknologi, Fakultas Pertanian Universitas Sebelas Maret Surakarta \\ Kontak Penulis: el.anshori.07@gmail.com
}

\begin{abstract}
Cabbage head caterpillar (Crocidolomia pavonana) is a major pest on Brassicaceae. Control using chemical insecticides to control this pest can resistance. When used as a lime peel essential oil is thought to be cabbage head caterpillar pest control compounds that contain monoterpene. This study is conducted in August 2016January 2017. This study used a completely randomized design (CRD) with one factor is the concentration of essential oil. Variables measured were Larvicide, antifeedant, antioviposition, and phytotoxocity. The research results showed that essential oil of lime peel cause mortality of larvae of $\mathrm{C}$. pavonana slowly. antifeedant activity due to the essential oil of less than $50 \%$. Inhibition of egg laying was significant at concentration of $0.2 \%(73.3 \%)$, $0.8 \%$ and $1.6 \%(80 \%)$. Essential oil causes necrosis of leaf less than $10 \%$.
\end{abstract}

Keywords: Larvicide, antifeedant, antioviposition, phytotoxocity

AGROTECHNOLOGY RESEARCH JOURNAL

Al Anshori NM, Wijayanti R, Sulistyo A. 2017. Potential of lime peel essential oil for contro/ Crocidolomia Pavonana. Agrotech Res J 1(2): 19-23.

Al Anshori NM, Wijayanti R, Sulistyo A. 2017. Potensi minyak atsiri kulit jeruk nipis untuk pengendalian Crocidolomia Pavonana. Agrotech Res J 1(2): 19-23.

\section{PENDAHULUAN}

Ulat kubis (Crocidolomia pavonana (F.) sinonim Crocidolomia binotalis Zeller) merupakan hama penting bagi tanaman kubis, sawi, dan brokoli. Ulat ini menjadi masalah yang serius dikarenakan ulat memakan daun yang masih muda serta menyerang titik tumbuh tanaman (Othman 1982). Jika yang terserang tanaman kubis maka tanaman masih bisa hidup sedangkan pada tanaman sawi tanaman tidak dapat bertahan hidup (Pracaya 1999).

Pengendalian dengan menggunakan insektisida kimia yang dilakukan petani dapat menyebabkan resistensi hama $C$. pavonana. Penggunaan insektisida tidak baik karena dapat menyebabkan hama menjadi resisten dan mengganggu keseimbangan lingkungan (Asriani et al. 2013). Dono et al. (2010) melaporkan, C. pavonana populasi Kerta, Payangan, Gianyar, Bali telah menunjukkan mekanisme resistensi terhadap insektisida profenofos dengan nilai nisbah resistensi $>7$. Kulit jeruk nipis merupakan limbah yang belum termanfaatkan dengan baik.

Berdasarkan hal tersebut, minyak atsiri kulit jeruk nipis memiliki kemungkinan yang besar dapat mengendalikan hama ulat kubis. Kulit jeruk nipis yang didestilasi mengandung senyawa aktif limonene $97,83 \%$ (Moraes et al. 2009). Buah jeruk nipis yang didestilasi mengandung senyawa pinene, camphene, cymene, limonene, ocimene, linalool, fenchol, verbenone, elemene, neryl acetate, caryophyllene, dan bergamotene (Patil 2009). Oleh karena itu, evaluasi potensi kulit jeruk nipis sebagai larvasida, Antifeedant dan repellent perlu dilakukan sebagai alternatif dalam

${ }^{\star}$ Fak. Pertanian UNS Surakarta

JI. Ir. Sutami 36 A Surakarta pengendalian hama $C$. Pavonana. Penelitian ini bertujuan untuk melihat seberapa besar potensi minyak atsiri kulit jeruk nipis terhadap pengendalian hama ulat kubis.

\section{BAHAN DAN METODE PENELITIAN}

Penelitian ini dilaksanakan pada bulan Agustus 2016 - Januari 2017. Bahan yang digunakan adalah kulit jeruk nipis, tanaman sawi, media tanam, Tween 80 dan ulat kubis (C. pavonana). Alat yang digunakan adalah petridish, botol kaca, pipet, gelas ukur, toples, kain kasa dan destilator.

Penelitian ini menggunakan Rancangan Acak Lengkap (RAL) dengan satu faktor yaitu konsentrasi minyak atsiri yang terdiri atas 7 taraf dan setiap konsentrasi diulang sebanyak 4 kali. Pada setiap perlakuan pada uji larvasida menggunakan 20 ekor larva ulat kubis dan uji antifeedant sebanyak 1 ekor. Pada uji fitotoksisitas menggunakan 1 tanaman sawi dan pada uji antioviposisi menggunakan 1 tanaman sawidan sepasang imago. Perlakuan yang digunakan adalah: $\mathrm{M} 1$ = aquadest (kontrol 1$), \mathrm{M} 2$ = aquadest dan Tween 80 dengan perbandingan 9:1 (kontrol 2), M3 = $0,1 \%$ minyak atsiri, M4 $=0,2 \%$ minyak atsiri, M5 $=0,4 \%$ minyak atsiri, $M 6=0,8 \%$ minyak atsiri, $M 7=1,6 \%$ minyak atsiri.

Mortalitas larva pada uji larvasida dihitung berdasarkan jumlah larva yang mati selama 4 hari. Hambatan aktivitas makan atau antifeedant dari minyak atsiri diketahui dengan menghitung luas daun yang dimakan larva setelah 24 jam. Jumlah koloni telur yang diletakkan imago pada tanaman inang dan dinding kandang oleh imago betina dewasa pada tanaman sawi. Fitotoksisitas untuk melihat pengaruh minyak atsiri kulit jeruk nipis terhadap tanaman sawi uji. 
Penghitungan persentase mortalitas larva, antifeedant, indeks antioviposisi dan luas relatif bercak nekrotik dianalisis terlebih dahulu dengan menggunakan Microsoft excel. Selanjutnya, Analisis statistik dilakukan dengan ANOVA dan uji DMRT menggunakan SPSS dengan tingkat kepercayaan 95\%. Data jumlah koloni telur yang diletakkan pada daun dan dinding pada uji antioviposisi dan data uji fitotoksisitas, ditransformasi terlebih dahulu sebelum dianalisis

\section{HASIL DAN PEMBAHASAN}

\section{Larvasida}

Berdasarkan pengamatan yang dilaksanakan, minyak atsiri kulit jeruk nipis terhadap larva uji dapat menimbulkan gejala berupa; (1) perubahan warna, yaitu tubuh larva menjadi berwarna kuning pucat, selanjutnya warnanya berubah lagi menjadi coklat kehitaman (mati); (2) gagal pupa, yaitu ulat yang akan menjadi pupa berwarna coklat kehitaman tubuhnya menyusut dan kering; (3) larva yang masih hidup bergerak lambat dan mengalami penurunan aktifitas makan).

Jumlah larva yang mati secara umum pada hari pertama setelah perlakuan relatif rendah.Jumlah larva yang mati pada hari kedua lebih rendah dari hari pertama. Mortalitas menurun karena larva mengalami hambatan aktivitas makan. Aktivitas makan yang menurun diduga menyebabkan kematian larva pada hari ketiga dan keempat. Aktivitas makan yang menurun juga dapat dijadikan indikasi adanya gangguan sistem pencernaan pada tubuh larva (Tabel 1). Menurut Dono dan Susanerwinur (2013), gangguan pada penerimaan rangsangan pada saat proses makan menyebabkan serangga uji tidak dapat melakukan aktivitas makan secara normal. Aktivitas makan yang terganggu menyebabkan sebagian atau seluruh nutrisi yang diperlukan serangga tidak dapat terpenuhi.

Tabel 1 Rata-rata jumlah larva $C$. pavonana yang mati akibat perlakuan dengan minyak atsiri kulit jeruk nipis.

\begin{tabular}{lrrrrrr}
\hline \multirow{2}{*}{ Perlakuan } & \multicolumn{4}{c}{$\mathrm{HSP}^{1)}$} & \multicolumn{3}{c}{ Total } \\
\cline { 2 - 6 } & $\mathrm{N}$ & 1 & 2 & 3 & 4 & Mortalitas \\
\hline Air & 80 & 0 & 0 & 1 & 0 & 1 \\
Air +tween & 80 & 0 & 0 & 1 & 2 & 3 \\
$0.1 \%$ & 80 & 5 & 4 & 9 & 3 & 21 \\
$0.2 \%$ & 80 & 6 & 4 & 11 & 5 & 26 \\
$0.4 \%$ & 80 & 18 & 2 & 9 & 3 & 32 \\
$0.8 \%$ & 80 & 10 & 0 & 16 & 8 & 34 \\
$1.6 \%$ & 80 & 15 & 9 & 20 & 10 & 54 \\
\hline
\end{tabular}

1) $\mathrm{HSP}=$ Hari Setelah Perlakuan

Rata-rata mortalitas larva meningkat seiring dengan bertambahnya konsentrasi minyak atsiri. Berdasarkan uji DMRT, mortalitas larva pada konsentrasi dibawah $1 \%$ tidak berbeda nyata. Konsentrasi $0.1 \%, 0.2 \%$, $0.4 \%$, dan $0.8 \%$ telah mampu menyebabkan mortalitas sebesar $26.25 \%, 32.5 \%, 40 \%$, dan $42.5 \%$. Mortalitas larva pada konsentrasi $1.6 \%$ sebesar $67.5 \%$ dan berbeda nyata dengan konsentrasi dibawah $1 \%$ (tabel 2).
Tabel 2 Rata-rata persentase mortalitas larva $C$. pavonana akibat perlakuan dengan minyak atsiri kulit jeruk nipis (\%)

\begin{tabular}{lrrrrrrr}
\hline \multirow{2}{*}{ Perlakuan } & \multicolumn{9}{c}{ Ulangan } & \multicolumn{3}{c}{ Rata-rata Mortalitas } \\
\cline { 2 - 7 } & 1 & 2 & 3 & 4 & \pm SB $^{1)}$ & & \\
\hline Air & 0 & 5 & 0 & 0 & 1.25 & \pm 2.16 & $\mathrm{a}^{2)}$ \\
Air+tween & 10 & 0 & 0 & 5 & 3.75 & \pm 4.15 & $\mathrm{a}$ \\
$0.1 \%$ & 25 & 10 & 35 & 35 & 26.25 & \pm 10.23 & $\mathrm{~b}$ \\
$0.2 \%$ & 30 & 35 & 30 & 35 & 32.5 & \pm 2.5 & $\mathrm{bc}$ \\
$0.4 \%$ & 35 & 55 & 30 & 40 & 40 & \pm 9.35 & $\mathrm{bc}$ \\
$0.8 \%$ & 40 & 50 & 35 & 45 & 42.5 & \pm 5.9 & $\mathrm{c}$ \\
$1.6 \%$ & 55 & 90 & 65 & 60 & 67.5 & \pm 13.46 & $\mathrm{~d}$ \\
\hline
\end{tabular}

1) $\mathrm{SB}=$ Simpangan Baku (standar deviasi)

2) Angka yang diikuti oleh huruf yang sama tidak berbeda nyata pada taraf $5 \%$ uji DMRT

Berdasarkan hasil penelitian, kecepatan daya bunuh dari minyak atsiri pada uji larvasida rendah dikarenakan sebagian senyawa menguap sebelum diberikan pada larva. Minyak atsiri kulit jeruk nipis mudah menguap (volatil) karena kandungan monoterpena yang cukup tinggi. Minyak atsiri kulit jeruk nipis setelah didestilasi mengandung senyawa limonene sebesar $44,59 \%$, linalool 5,06\%, citronellol 9,72\%, dan geraniol $11,96 \%$ (Tjokronegoro et al. 2008).

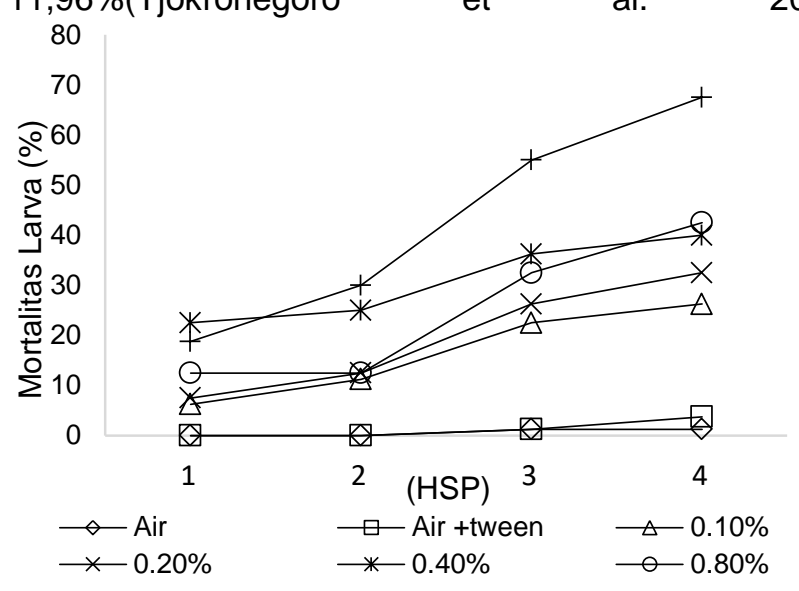

Gambar 1 Grafik perkembangan mortalitas larva $C$. pavonana.

\section{Antifeedant}

Minyak atsiri kulit jeruk nipis dapat mempengaruhi aktivitas makan dari larva C. pavonana. Hambatan aktivitas makan atau antifeedant akibat minyak atsiri kurang dari $50 \%$ (Tabel 3 ). serangga juga bisa mengambil strategi dengan meningkatkan laju konsumsi. Meningkatnya laju konsumsi, maka makanan harus segera diproses dan tidak bisa disimpan di pencernaan, akibatnya efisiensi makanan di konsumsi dan efisiensi makanan dicerna bisa mengalami penurunan (Lina et al. 2015). Senyawa pada minyak atsiri bersifat antifeedant pada larva C. pavonana namun lemah. Insektisida nabati berbahan aktif citronellal lebih bersifat sebagai antifeedant terhadap $C$. pavonana (Willis et al. 2011). 
Tabel 3 Persentase hambatan aktivitas makan dari larva C. pavonana (\%).

\begin{tabular}{lrrrrrr}
\hline \multirow{2}{*}{ Perlakuan } & \multicolumn{3}{c}{ Ulangan } & & Rata-rata $\pm \mathrm{SB}^{1)}$ \\
\cline { 2 - 5 } & 1 & 2 & 3 & 4 & & \\
\hline Air & 6.05 & 10.90 & -8.47 & -8.47 & $0.00 \pm 0.00$ & $\mathrm{a}^{21}$ \\
Air+tween & 10.90 & 17.68 & 7.02 & 2.18 & $9.44 \pm 5.67$ & ab \\
$0.1 \%$ & 27.36 & 46.73 & 36.08 & 19.61 & $32.45 \pm 10.1$ & $\mathrm{C}$ \\
$0.2 \%$ & 38.01 & 19.61 & 24.46 & 23.49 & $26.39 \pm 6.95$ & $\mathrm{C}$ \\
$0.4 \%$ & 32.20 & 40.92 & 32.20 & 12.83 & $29.54 \pm 10.3$ & $\mathrm{C}$ \\
$0.8 \%$ & 20.58 & 22.52 & 28.33 & 15.74 & $21.79 \pm 4.51$ & $\mathrm{bc}$ \\
$1.6 \%$ & 44.79 & 25.42 & 18.64 & 26.39 & $28.81 \pm 9.70$ & $\mathrm{C}$ \\
\hline
\end{tabular}

1) $\mathrm{SB}$ = Simpangan Baku (standar deviasi)

2) Angka yang diikuti oleh huruf yang sama tidak berbeda nyata pada taraf $5 \%$ uji DMRT

\section{Antioviposisi}

Berdasarkan hasil penelitian, jumlah koloni telur yang diletakkan paling banyak pada perlakuan air dan tween 80. Jumlah koloni telur lebih banyak daripada perlakuan air sehingga indeks antioviposisi menjadi $46,7 \%$. Penghambatan peletakan telur tertinggi pada perlakuan konsentrasi 0,8 dan 1,6 yakni sebesar $80 \%$ (Tabel 4). Perlakuan konsentrasi $0,8 \%$ dan $1,6 \%$ terdapat ulangan yang mencapai $100 \%$ atau tidak ada telur yang diletakkan. Hal ini dikarenakan mortalitas imago pada 2 HSP. Imago mati diduga karena senyawa pada minyak atsiri yang menguap dan mengganggu pernapasan imago. Senyawa monoterpena dapat bersifat repellent karena mudah menguap (volatil). Senyawa yang bersifat volatil diterima oleh saraf olfactory sebagai faktor penghambat peletakan telur (Wiyantono et al. 2001).

Jumlah koloni telur pada daun sawi lebih banyak dari koloni telur pada dinding. Jumlah koloni telur pada dinding terbanyak yakni pada perlakuan $0,2 \%$ sebesar $3,75 \%$ dan berbeda nyata dari perlakuan lain. Tidak ada koloni telur pada perlakuan $0,8 \%$ dan $1,6 \%$ didinding, hal ini menunjukkan bahwa minyak atsiri bersifat repellent sekaligus fumigan yang kuat. Menurut Syahbirin et al. (2011), volatilitas minyak atsiri yang besar menyebabkan minyak atsiri juga dapat berperan sebagai fumigan yaitu racun yang bekerja melalui sistem pernapasan. Menurut Dehgani dan Ahmadi (2013), semakin volatil suatu minyak atsiri maka semakin kuat pengaruh repellent dan antioviposisinya.

Tabel 4 Persentase peletakan telur dan Indeks antioviposisi oleh imago betina C. pavonana (\%).

\begin{tabular}{llrl}
\hline \multirow{2}{*}{ Perlakuan } & \multicolumn{2}{c}{ Jumlah koloni telur } & Indeks anti oviposisi \pm SB ${ }^{11}$ \\
\cline { 2 - 3 } Air & Pada daun & Pada dinding & \\
Air+tween & $3.75 \pm 0.83 \mathrm{bc}$ & $0.00 \pm 0.0 \mathrm{a}$ & $0.00 \mathrm{a}$ \\
$0.1 \%$ & $5.50 \pm 1.80 \mathrm{c}$ & $0.50 \pm 0.5 \mathrm{a}$ & $-46.7 \mathrm{a}$ \\
$0.2 \%$ & $3.75 \pm 0.43 \mathrm{bc}$ & $0.50 \pm 0.5 \mathrm{a}$ & $0.00 \mathrm{a}$ \\
$0.4 \%$ & $1.00 \pm 0.71 \mathrm{a}$ & $3.75 \pm 2.8 \mathrm{~b}$ & $73.3 \mathrm{~b}$ \\
$0.8 \%$ & $1.75 \pm 0.43 \mathrm{ab}$ & $0.75 \pm 1.3 \mathrm{a}$ & $53.3 \mathrm{~b}$ \\
$1.6 \%$ & $0.75 \pm 1.30 \mathrm{a}$ & $0.00 \pm 0.0 \mathrm{a}$ & $80.0 \mathrm{~b}$ \\
\hline
\end{tabular}

1) $\mathrm{SB}=$ Simpangan Baku (standar deviasi)

2) Angka yang diikuti oleh huruf yang sama tidak berbeda nyata pada taraf $5 \%$ uji DMRT

Efektivitas antipeletakan telur tersebut meningkat dengan semakin meningkatnya konsentrasi minyak atsiri. Imago Betina mulai meletakkan telur pada hari ke empat bertambah sedikit demi sedikit pada hari selanjutnya. Peletakan telur dimulai pada hari ke empat diduga karena minyak atsiri telah berkurang efektivitasnya (Gambar 2). Pestisida berbasis minyak atsiri memiliki kekurangan yakni sifat volatil dan tidak stabil atau tidak tahan terhadap sinar matahari (Hartati 2012). Tempat pengujian dibawah sinar matahari diduga mempengaruhi presistensi minyak atsiri. Menurut Dadang et al (2007), insektisida asal tumbuhan mudah terurai oleh cahaya matahari sehingga memiliki persistensi yang singkat di lapangan. Persistensi merupakan jangka waktu senyawa aktif insektisida masih mempunyai aktivitas biologi.

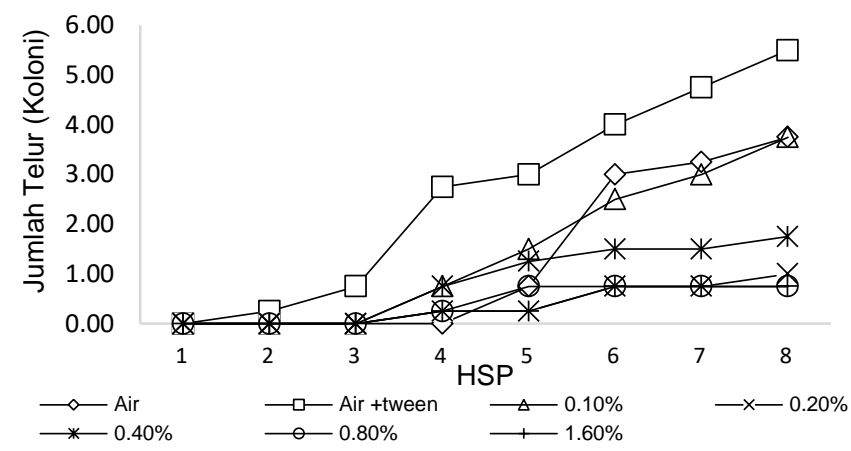

Gambar 2 Jumlah peletakan telur oleh imago betina $C$. pavonana pada permukaan daun (koloni).

Serangga yang berbeda memiliki sensitivitas hambatan peletakan telur yang berbeda pula. Senyawa limonene dan, linalool bersifat insektisida fumigan atau racun pernapasan bagi Sitophilus zeamais dewasa (Yildirim et al. 2013). Cineole dan myrcene bersifat 
fumigan terhadap Sitophilus oryzae (Abdelgaleil dan badawy 2009). Cineole dan betha pinene memiliki repelensi yang tinggi terhadap Sitophilus zeamais dewasa (Wang et al. 2009).

\section{Fitotoksisitas}

Berdasarkan hasil pengamatan, gejala nekrosis akibat efek fitotoksik dari larutan uji terlihat pada ujung daun sawi. Efek fitotoksik terlihat dengan gejala daun tampak warna memudar pada hari pertama setelah perlakuan. Hari kedua, ujung daun mengering dan melengkung kedalam. Hari ketiga, daun yang mengering berubah warna menjadi kekuningan dan keriting. Hari selanjutnya, daun berubah menjadi kuning kecoklatan.

Nekrosis yang terjadi pada daun sawi tidak lebih dari $10 \%$. Luas relatif bercak nekrotik beragam seluruh perlakuan yang menggunakan tween 80 (Tabel 5). Tween 80 diduga dapat menyebabkan kerusakan pada daun tanaman sawi. Tween 80 (Polyethylene glycol sorbitan monooleat) adalah surfaktan nonionik yang berfungsi sebagai emulsifier minyak dalam air (Feng et al. 2006). Kandungan senyawa monoterpena dalam minyak atsiri juga diduga dapat bersifat fitotoksik. Gejala fitotoksik cenderung terjadi pada tanaman yang diberi perlakuan sediaan ekstrak/fraksi insektisida nabati, bukan senyawa murni (Syahputra et al. 2007).

Tabel 5 Rata-rata persentase luas relatif bercak nekrotik pada daun sawi (\%).

\begin{tabular}{lrrrrlll}
\hline \multirow{2}{*}{ Perlakuan } & \multicolumn{9}{c}{ Ulangan } & \multicolumn{2}{c}{ Rata-rata $\pm \mathrm{SB}^{1)}$} \\
\cline { 2 - 6 } & 1 & 2 & 3 & 4 & $0.00 \pm 0$ & $\mathrm{a}^{2)}$ \\
\hline Air & 0.00 & 0.00 & 0.00 & 0.00 & 3.34 & \pm 1.05 & $\mathrm{~b}$ \\
Air+tween & 2.19 & 3.17 & 2.96 & 5.05 & $6.56 \pm 1.77$ & $\mathrm{~b}$ \\
$0.1 \%$ & 3.96 & 8.57 & 7.73 & 5.96 & $6.59 \pm 1.48$ & $\mathrm{~b}$ \\
$0.2 \%$ & 5.56 & 4.86 & 8.63 & 7.33 & $4.71 \pm 2.46$ & $\mathrm{~b}$ \\
$0.4 \%$ & 2.52 & 2.81 & 8.67 & 4.85 & $6.30 \pm 1.15$ & $\mathrm{~b}$ \\
$0.8 \%$ & 7.14 & 6.19 & 7.39 & 4.47 & $3.82 \pm 2.73$ & $\mathrm{~b}$ \\
$1.6 \%$ & 7.07 & 0.75 & 1.53 & 5.95 &
\end{tabular}

1) SB = Simpangan Baku (standar deviasi)

2) Angka yang diikuti oleh huruf yang sama tidak berbeda nyata pada taraf $5 \%$ uji DMRT

Penggunaan surfaktan pada kadar yang lebih tinggi akan berkumpul membentuk agregat yang disebut misel (Attwood dan Florence 1985). Surfaktan dengan kadar tinggi sampai Critical Micelle Concentration (CMC) maka surfaktan diasumsikan mampu berinteraksi kompleks dengan obat tertentu selanjutnya dapat pula mempengaruhi permeabilitas membran tempat absorbsi obat karena surfaktan dan membran mengandung komponen penyusun yang sama (Sudjaswadi 1991). Apabila permeabilitas membran menjadi rusak maka mengakibatkan kematian sel. Tween 80 pada konsentrasi tinggi dapat menyebabkan terjadinya nekrosis.

Senyawa monoterpena pada minyak atsiri kulit jeruk nipis dapat bersifat fitotoksik pada tanaman tergantung pada bagian, umur dan jenis tanaman yang di uji. Limonene dan alpha pinene tidak bersifat fitotoksik pada akar bibit padi (Zhang et al. 2012). Senyawa monoterpenoid (myrcene, limonene, pinene, linalool dan citral) menyebabkan kerusakan pada daun dan batang bibit selada namun lemah (Fujii et al. 2005).

\section{KESIMPULAN DAN SARAN}

\section{Kesimpulan}

Kesimpulan yang dapat diambil dari penelitian ini adalah:

1. Minyak atsiri kulit jeruk nipis dapat mempengaruhi ulat kubis atau C. pavonana secara lambat.

2. Mortalitas larva pada konsentrasi $1,6 \%$ sebesar $67,5 \%$. Hambatan aktivitas makan akibat minyak atsiri kurang dari 50\%. Penghambatan peletakan telur signifikan pada konsentrasi $0,2 \%, 0,8 \%$ dan $1,6 \%$. Tween 80 menyebabkan nekrosis pada daun sawi kurang dari $10 \%$.

\section{Saran}

Saran yang dapat penulis berikan bagi penelitian ini adalah petani dapat menggunakan minyak atsiri kulit jeruk nipis sebagai pestisida hama $C$. pavonana dengan konsentrasi 1,6\% untuk pengendalian larva dan konsentrasi 0,2\% untuk pengendalian imago.

\section{DAFTAR PUSTAKA}

Abdelgaleil SAM, Badawy MEI. 2009. Fumigant and Contact Toxicities of Monoterpenes to Sitophilus oryzae (L.) and Tribolium castaneum (Herbst) and their Inhibitory Effects on Acetylcholinesterase Activity. J Chem Ecol. 35: 518-525. DOI: 10.1007/s10886.009.9635.3.

Asriani N W, Bagus IGN, Darmiati NN. 2013. Keragaman dan kepadatan populasi predator yang berasosiasi dengan hama penting pada tanaman kubis (Brasica oleraceae L.). J Agroteknologi Tropika. 2(3): 155-164.

Attwood D, Florence AT. 1985. Surfactan System. 1st Ed. London: Chapman and Hall.

Dadang, Isnaeni N, Ohsawa K. 2007. Ketahanan dan pengaruh fitotoksik campuran ekstrak Piper retrofractum dan annona squamosa pada pengujian semi lapangan. J HPT Tropika. 7 (2): 91 - 99.

Dehgani M, Ahmadi K. 2013. Repellence and antioviposition activities of plant products on greenhouse whitefly. Pharmacognosy Com. 3 (2):2-5. DOI:10.5530/pc.2013.2.2.

Dono, Ismayana S, Idar, Prijono D, Muslikha I. 2010. Status Dan Mekanisme Resistensi Biokimia Crocidolomia pavonana (F.) (Lepidoptera: Crambidae) terhadap Insektisida Organofosfat serta Kepekaannya terhadap Insektisida Botani Ekstrak Biji 
Barringtonia asiatica. J Entomol. Indon. 7(1): 9-27. DOI: $10.5994 /$ jei719.

Dono, Susanerwinur. 2013. Toksisitas dan anti oviposisi ekstrak metanol kulit biji jambu mete Anacardium occidentale L.) (Anacardiaceae) terhadap Crocidolomia pavonana F. (Lepidoptera: Pyralidae). Bionatura 15(2): 79 - 82.

Feng JH, Zeng YY, Ma CQ, Cai XF, Zhang Q, Tang MY, Yu B, Xu P. 2006. The Surfactant Tween 80 Enhances Biodesulfurization. Applied and Environmental Microbiology 72 (11): 7390-7393. DOI:10.1128/AEM.014.74.06

Fujii Y, Matsuyama M, Hiradate S, Shimozawa H. 2005. Dish pack method: a new bioassay for volatile allelopathy. Proceedings of the 4th World Congress on Allelopathy, "Establishing the Scientific Base", Wagga Wagga, New South Wales, Australia, 21-26 August 2005.

Hartati SY 2012. Prospek Pengembangan Minyak Atsiri Sebagai Pestisida Nabati. Perspektif 11 (1): 45 - 58.

Lina, Dadang, Manuwoto S, Syahbirin G. 2015. Gangguan fisiologi dan biokimia Crocidolomia pavonana (F.) (Lepidoptera: Crambidae) akibat perlakuan ekstrak campuran Tephrosia vogelli dan Piper aduncum. J Entomologi Indonesia. 12 (2): 100107. DOI: 10.5994/jei.12.2.100.

Moraes TM, Helio K, Fabio CM, Raquel CS, Lucia RMR, Marcia OM, wagner V, Cleilia AH. 2009. Effect of limonene and essential oil from Citrus aurantifolia on gastric mucosa: role of prostaglandins and Gastric mucus secretion. J. CBI 180 (2009): 499-505.

Othman N. 1982. Biology of Crocidolomia binotalis Zell. (Lepidoptera: Pyralidae) and Its Patasites From Cipanas Area (West Java). Bogor: Seameo Regional Center for Tropical Biology.

Patil JR, Jayaprakasha GK, Murthy KNC, Tichy SE, Chetti MB. 2009. Apoptosis-mediated proliferation inhibition of human colon cancer cells by volatile principles of Citrus aurantifolia. J Food chemistry.114 (2009): 1351-1358.

Pracaya. 1999. Hama dan Penyakit Tanaman. Jakarta: Penebar Swadaya.

Sudjaswadi R. 1991. Tween 80 dan Stabilitas Asetosal. Majalah Farmasi Indonesia 2(1): 28-34.
Syahbirin G, Hertika C, Prijono D, Dadang. 2011. Potensi minyak atsiri daun Cinnamomum multiflorum sebagai insektisida nabati terhadap ulat kubis Crocidolomia pavonana. dalam Dahlan K, Maddu A, Supena EDJ, Miftahudin, Nugrahani EH, Kusnanto A, Mulijani S, Sulistiyani (eds). prosiding Seminar Nasional Sains IV.Bogor. Peran Sains dalam Peningkatan Produktivitas Pertanian. 235-246.

Syahputra, Prijono D, Dono D. 2007. Sediaan insektisida Calophyllum soulattri: aktivitas insektisida dan residu terhadap larva Crocidolomia pavonana dan keamanan pada tanaman. J HPT Tropika. 7(1): $21-29$.

Tjokronegoro RK, Murad S, Imron SS, Asnani H. 2008. A New Formulation Of Insecticide, Repellent, And Larvicide Against Mosquitoes From The Waste Product Of Jeruk Nipis (Citrus Aurantifolia). Jatinangor (ID): Proceeding Of The International Seminar In Chemistry.

Wang Y, You CX, Wang CF, Yang K, Chen R, Zhang WJ, Du SS, Geng ZF, Deng ZW. 2014. Chemical constituents and insecticidal activities of the essential oil from amomum tsaoko against two stored-product insects. J Oleo Sci. 63(10): 1019-1026. DOI: 10.5650/jos.ess14.08.7.

Willis M, Wiratno D, WahyunoT E, Wahyono, Sondang S. 2011. Pemanfaatan limbah tanaman atsiri sebagai repelen hama Crocidolomia binotalis pada brokoli $(30 \%)$ dan pupuk organik ( $2 \%$ kadar N). Laporan Teknis Penelitian Tahun Anggaran 2011. Balai Penelitian Tanaman Rempah dan Obat.

Wiyantono, Prijono D, Manuwoto S. 2001. Bioaktivitas ekstrak biji Aglaia harmsiana terhadap ulat krop kubis Crocidolomia pavonana. J II Pert Indon. 10(1): 1-7.

Yildirim E, Emsen B, Kordali S. 2013. Insecticidal effects of monoterpenes on Sitophilus zeamais Motschulsky (Coleoptera: Curculionidae). Journal of Applied Botany and Food Quality. 86(1): 198 - 204. DOI: 10.5073/JABFQ.2013.086.027.

Zhang FJ, Guo JY, Chen FX, Liu WX, Wan FH. 2012. Identification of Volatile Compounds Released by Leaves of the Invasive Plant Croftonweed (Ageratina adenophora, Compositae), and their Inhibition of Rice Seedling Growth. weed science 60(2): 205-211. DOI:10.1614/WSD.11.00156.1. (Abstr). 